\title{
INTER-BUDGETARY RELATIONS IN UKRAINE IN MODERN CONDITIONS
}

\author{
L. Shirinyan, S. Esh \\ National University of Food Technologies
}

\begin{tabular}{l}
$\quad$ Key words: \\
Inter-budgetary relations \\
Transfers \\
Budget system \\
United territorial \\
communities \\
Local budgets \\
Incomes of local budgets \\
\hline \multicolumn{1}{c}{ Article history: } \\
Received 11.07.2018 \\
Received in revised form \\
25.07.2018 \\
Accepted 21.08.2018 \\
\hline
\end{tabular}

Corresponding author:

L. Shirinyan

E-mail:

npnuht@ukr.net

\begin{abstract}
The paper examines the financial component of interbudgetary relations in Ukraine and defines the ways of selfreplenishment of local budgets by cash resources.

It is substantiated that self-sufficiency of territories depends on the most part on its own financial resources: tax and non-tax revenues, the efficient use of capital operations concentrated in local budgets. Statistical analysis reveals an increase in the number of local budgets and a decrease in regional budgets. Such changes are related to the process of decentralization and the creation of united territorial communities.
\end{abstract}

The paper analyzes the composition and structure of local budget revenues. It is shown that an important part of the modern national budget policy is intergovernmental transfers (subventions and subsidies) that should help economicaly poor developed territories. There is a high share of funds of local budgets in the form of intergovernmental transfers at the level of $54,3 \%$ of all local budget revenues.

It is found that during 2016-2017 revenues to local budgets increased mainly due to the personal income tax. Revenues to local budgets from local taxes and fees was about $46 \%$ of all revenues.

In general, the usage of the state budget is aimed not so much at helping to develop entrepreneurship and improve the socio-economic state as to cover the expenditures of those territories, that are themselves unable to provide economic growth.

The analysis shows that in Ukraine, the most problematic in the social sphere are two branches - education and health care, which require significant investments, effective results from the implementation of reforms, a stable legislative framework.

It is argued that the centralization of tax revenues makes local budgets dependent on the state budget. In this respect it is proposed the optimization of distribution of local budget revenues: more than $70 \%$ of fiscal revenues should be formed due to own regional and local taxes.

DOI: $10.24263 / 2225-2924-2018-24-4-13$ 


\section{МІЖБЮДЖЕТНІ ВІДНОСИНИ В УКРАЇНІ В СУЧАСНИХ УМОВАХ}

\section{Л.В. Шірінян, С.М. Еш}

Національний університет харчових технологій

У статті досліджується фінансова складова міжбюджетних відносин в Украӥні та визначаються напрями самостійного поповнення місиевих бюджетів грошовими коштами.

Обтрунтовано, що забезпечення самодостатності територій більшою мірою залежить від власних фінансових ресурсів: податкових $і$ неподаткових надходжень, умілого використання операцій з капіталом, що зосереджується y місиевих бюджетах. Статистичний аналіз виявляе зростання кількості місиевих бюджетів $і$ зменшення районних бюджетів. Такі зміни пов'язані з прочесом децентралізачії і створенням об'єднаних територіальних громад.

Також проаналізовано склад і структуру доходів місиевих бюджетів. Показано, що важливою складовою сучасної національної бюджетної політики є міжбюджетні трансферти (субвениії та дотаиіï), які повинні допомогти бідним за економічним розвитком територіям. Спостерігається висока частка грошових коштів місиевих бюджетів у формі міжбюджетних трансфертів на рівні 54,3\% усіх доходів місиевих бюджетів.

Виявлено, що протягом 2016-2017 рр. доходи до місиевих бюджетів збільшились здебільшого за рахунок податку на доходи фізичних осіб. Надходження до місиевих бюджетів від місиевих податків і зборів становлять близько 46\% усіх доходів.

У иілому спостерігається спрямування коштів державного бюджету не на допомогу розвитку підприємництва та покращення соціально-економічного стану, а на покриття видатків тих територій, які самостійно не спроможні забезпечити економічне зростання.

Аналіз показав, щуо в Україні найпроблемнішими у соціальній сфері є дві галузі - че освіта та охорона здоров'я, які потребують значних інвестичій, ефективних результатів від проведення реформ, стабільної законодавчої бази.

Аргументовано, що иентралізація податкових доходів робить місиеві бюджети залежними від державного бюджету. Запропоновано оптимізацію розподілу доходів місиевих бюджетів: більше 70\% фіскальних надходжень має формуватися за рахунок власних регіональних і місиевих податків.

Ключові слова: міжбюджетні відносини, трансферти, бюджетна система, об'єднані територіальні громади, місиеві бюджети, доходи місцевих бюджетів.

Постановка проблеми. Під час формування бюджетної політики країни важливе місце займає перерозподіл фінансових ресурсів, особлива частка яких спрямовується у місцеві бюджети територіальних громад. Нині в Україні не всі регіони мають достатні власні ресурси для забезпечення нормаль- 
ного розвитку своїх територій у повному обсязі. Тому важливою складовою сучасної національної бюджетної політики є міжбюджетні трансферти: субвенції та дотації, які повинні допомогти бідним за економічним розвитком територіям. Уряд розпочав процес децентралізації, який передбачає зменшення частки такої допомоги з одночасним розв'язанням проблем, пов'язаних із забезпеченням економічного зростання регіонів.

Аналіз останніх досліджень і публікацій. Сучасні аспекти міжбюджетних відносин в Україні проаналізовано в працях українських науковців (Т.М. Завора [1], Л.Б. Рябушка [2], І.О. Луніна [3], Н.В. Корень [4], К. Обуховська [5], I.C. Волохова [6] та ін.). На нашу думку, залишаються недостатньо опрацьованими теоретичні та практичні аспекти підвищення рівня використання інструментарію місцевого самоврядування як складової успішного соціально-економічного розвитку регіонів.

Метою статті $є$ дослідження фінансової складової міжбюджетних відносин в Україні та визначення напрямів самостійного поповнення місцевих бюджетів грошовими коштами.

Викладення основних результатів дослідження. За роки незалежності в Україні в міжбюджетних відносинах вже сформовано відповідний механізм взаємодії, до якого входять місцеві бюджети, трансферти, територіальні громади.

Згідно з чинним законодавством бюджетна система України є сукупністю державного бюджету та місцевих бюджетів, побудованих з урахуванням економічних відносин, державного й адміністративно-територіальних устроїв, i врегульована нормами права [7]. Державний бюджет постійно взаємодіє 3 місцевими бюджетами, про що свідчать показники табл. 1.

Таблиця 1. Кількість місцевих бюджетів, з якими здійснювалися взаємовідносини державного бюджету в 2016-2017 р., розраховано авторами за джерелами [8; 9]

\begin{tabular}{|c|c|c|c|}
\hline Назва бюджетів & 2016 & 2017 & Відхилення \\
\hline Місцеві бюджети, всього & 793 & 998 & 205 \\
\hline Бюджети міст обласного значення & 148 & 148 & без змін \\
\hline $\begin{array}{c}\text { Бюджети об’єднаних територіальних } \\
\text { громад (ОТГ) }\end{array}$ & 159 & 366 & 207 \\
\hline Районні бюджети & 461 & 459 & -2 \\
\hline Бюджети міста Києва & 25 & 25 & без змін \\
\hline
\end{tabular}

Дані табл. 1 свідчать про зростання кількості місцевих бюджетів (що спостерігаємо в їх загальній кількості та ОТГ) і зменшення районних бюджетів. Такі зміни пов'язані з процесом децентралізації і створенням об'єднаних територіальних громад. Збільшення місцевих бюджетів на 205 одиниць зумовлене збільшенням кількості територіальних громад на 207, які формують свої самостійні бюджети.

Територіальні громади у своєму розпорядженні мають вагомі фінансові ресурси, які можна спрямувати на розвиток своєї території без допомоги держави. Тому одним із вирішальних питань бюджетної політики є створення ефективної моделі побудови місцевих бюджетів, оскільки механізм ії функціонування та ефективного використання прямо впливає на добробут населе- 
ння та соціально-економічний розвиток регіону і країни в цілому. Відповідно до ст. 9 Бюджетного кодексу України доходи бюджету класифікуються за такими розділами: податкові надходження, неподаткові надходження, доходи від операцій з капіталом і трансферти, які згідно з Бюджетним кодексом поділяють на дотації і субвенції [7].

У табл. 2 представлено динаміку надходжень до місцевих бюджетів протягом 2016-2017 років. Дані табл. 2 свідчать, що протягом 2016-2017 рр. доходи до місцевих бюджетів збільшились на 136 млрд грн, частка у такому збільшенні міжбюджетних трансфертів становить 77,2 млрд грн. Із загальної суми всіх надходжень, отриманих місцевими бюджетами, обсяг податків i зборів, які справлялись на їх території, становить 229,5 млрд грн.

Таблиия 2. Доходи місцевих бюджетів 2017 р. порівняно з 2016 р., розраховано авторами за даними джерела [9]

\begin{tabular}{|c|c|c|c|c|c|}
\hline $\begin{array}{c}\text { Назва доходу } \\
\text { (млрд грн) }\end{array}$ & 2016 & $\begin{array}{c}\text { \% у загальній } \\
\text { сумі }\end{array}$ & 2017 & $\begin{array}{c}\% \text { у загальній } \\
\text { сумі }\end{array}$ & $\begin{array}{c}\text { Абсолютне } \\
\text { відхилення }\end{array}$ \\
\hline $\begin{array}{c}\text { Доходи з урахуванням } \\
\text { міжбюджетних трансфертів }\end{array}$ & 366,1 & 100 & 502,1 & 100 & 136,0 \\
\hline $\begin{array}{c}\text { у тому числі: } \\
\text { доходи без врахування } \\
\text { міжбюджетних } \\
\text { трансфертів }\end{array}$ & 170,7 & 46,6 & 229,5 & 45,7 & 58,8 \\
\hline з них: & 76,9 & 21,0 & 108,3 & 21,6 & 31,4 \\
\hline $\begin{array}{c}\text { податок на доходи } \\
\text { фізичних осіб }\end{array}$ & 11,6 & 3,2 & 13,2 & 2,6 & 1,5 \\
\hline акцизнй податок & 7,1 & 1,9 & 8,3 & 1,6 & 1,2 \\
\hline земельний податок & 13,4 & 3,6 & 14,7 & 2,9 & 1,4 \\
\hline орендна плата & 10,3 & 2,8 & 15,4 & 3,1 & 5,1 \\
\hline єдиний податок & 14,5 & 14,1 & 69,6 & 13,9 & 18,1 \\
\hline інші податки та збори & 51,5 & 53,4 & 272,6 & 54,3 & 77,2 \\
\hline офіційні трансферти & 195,4 & & & \\
\hline
\end{tabular}

Детальний аналіз наведених у табл. 2 результатів виявляє, що відповідне збільшення відбулось за рахунок:

- податку на доходи фізичних осіб, що сплачується платниками податку 3 заробітної плати та грошового забезпечення, на 31,4 млрд грн;

- єдиного податку з фізичних осіб на 5,1 млрд грн;

- акцизного податку на 1,5 млрд грн;

- орендної плати з юридичних осіб на 1,4 млрд грн;

- земельного податку з юридичних осіб на 1,2 млрд грн;

- інших податків та зборів на 18,1 млрд грн.

Незначну частку у внесеннях до місцевих бюджетів займають податок на прибуток підприємств - 6485 млн грн (3\%), та плата за користування надрами -1 103 млн грн (1\%), які ввійшли до групи «інші податки та збори» [9]. Згідно з внесеними змінами до Бюджетного кодексу України, важливим моментом $€$ те, що вирівнювання (допомога відсталим бюджетам) здійснюється саме за доходами місцевих бюджетів, що впливає на механізм формування бюджетів. 
Розглянемо відсоткову структуру доходів місцевих бюджетів за даними для 2017 р. (табл. 2). Якщо аналізувати основні розділи доходів місцевих бюджетів за бюджетною класифікацією, то спостерігаємо, що податкові надходження становлять близько 40,7\%, неподаткові надходження $-5 \%$, міжбюджетні трансферти - 54,3\% [4]. Отже, спостерігається висока частка грошових коштів місцевих бюджетів у формі трансфертів [2].

Зазвичай, більша частина загальнодержавних податків і зборів, зібраних на місцевому рівні, перерозподіляються до державного бюджету. На практиці при розподілі грошових коштів відбувається кругообіг: місцеві бюджети перераховують частину (або й повністю) відрахувань від державних податків і зборів до державного бюджету, що формує його доходи.

Дані табл. 2 свідчать, що надходження до місцевих бюджетів від місцевих податків і зборів (які являють собою доходи без урахування міжбюджетних трансфертів) $\epsilon$ незначними і становлять для 2017 р. близько 45,7\% усіх доходів. На нашу думку, це не дає можливостей для достатнього розвитку територій, тому виникає проблема фінансового вирівнювання, коли держава допомагає бідним територіям. За умов фінансового вирівнювання кошти, які місцеві бюджети перерахували до державного бюджету, отримують назад у формі дотацій чи субвенцій. Як бачимо, частка таких трансфертів становить близько 54\% для 2017 року. У зв'язку з цим доцільно було б збільшити частку податкових надходжень, яку необхідно залишати на території їх збирання для надання можливості органам місцевого самоврядування вкласти ці кошти у розвиток територій.

Централізація податкових доходів породжує не лише суперечності між учасниками різних рівнів бюджетної системи, а й робить місцеві бюджети значно залежними від державного бюджету. Саме тому доцільною є оптимізація розподілу доходів місцевих бюджетів, коли більше $70 \%$ фіскальних надходжень має формуватися за рахунок власних регіональних і місцевих податків. Такий підхід дасть можливість зменшити ризик корупційних зловживань збоку чиновників. Він притаманний багатьом розвинутим країнам, приміром, таким як Велика Британія, Швейцарія, Швеція, Нова Зеландія, Ісландія, Данія, де частка надходжень за рахунок місцевого податків із зборів становить близько 90\%. Водночас слід зауважити, що у світі існують також інші приклади. Високим рівнем централізації доходів відрізняються США, де федеральний уряд концентрує приблизно 58\% загальнодержавних доходів, Греція - 97\%, Бельгія і Франція - 82\%, Австрія та Нідерланди $90 \%[7$, c. 36].

Важливим джерелом надходжень до місцевого бюджету $є$ неподаткові надходження - це переважно доходи від державної власності, підприємницької діяльності та фінансових санкцій. Проведений аналіз структури неподаткових надходжень до місцевих бюджетів показує, що найбільшу їх частку займають надходження з бюджетних установ - 16949 млн грн $(65 \%)$, власні фінансові ресурси є значно меншими: адміністративні збори та платежі 3981 млн грн (15\%), інші надходження - 2698 млн грн (11\%), доходи державних підприємств становлять усього 2341 млн грн (9\%) [8]. 
Органи місцевого самоврядування при розв'язанні проблем фінансового забезпечення можуть скористатися саме джерелами неподаткових надходжень, якщо останні будуть правильно сплановані. В українських територіальних громадах майже відсутня муніципальна власність, що негативно відображається на загальній сумі місцевого бюджету. На нашу думку, аграрний сектор, промислові підприємства, які розміщені на території регіонів, поки що не дають достатніх надходжень до місцевих бюджетів, оскільки потребують заміни обладнання, втілення нових технологій, тобто достатніх інвестицій. Загалом, питання формування муніципальної власності, спроможної забезпечити надходження до бюджету і підвищити рівень життя громад, нині $є$ вельми актуальним. Як вирішення подібної проблеми можна навести приклад переходу до муніципальної власності АТ «Київенерго» у м. Київ.

Не викликає сумнівів, що збільшення коштів у місцевий бюджет може забезпечити розвиток підприємницької діяльності і зростання добробуту громадян, які нею займаються, і громади в цілому, яка отримує кошти для свого розвитку у формі податків від підприємницької діяльності. Території зможуть самостійно покривати видатки, а отже, менше потребуватимуть трансфертів.

В Україні регіони характеризуються різним соціально-економічним рівнем розвитку територіальних громад. Відповідний поділ на законодавчому рівні існує з 2006 р. після набуття чинності законом «Про стимулювання розвитку регіонів» [12]. Саме тому доцільно дослідити ситуацію щодо надання допомоги регіонам України через трансферти, яка склалася останніми роками для визначення ступеня важливості державних дотацій і субвенцій в сучасних умовах (табл. 3). Надходження дотацій і субвенцій з державного до місцевих бюджетів протягом 2017 р. склали 272078 млн грн.

Таблиия 3. Частка міжбюджетних трансфертів у місцевих бюджетах, складено авторами за даними джерел [8;9]

\begin{tabular}{|c|c|c|c|}
\hline Роки & $\begin{array}{c}\text { Місцеві бюджети (3 } \\
\text { урахуванням трансфертів), } \\
\text { млн грн }\end{array}$ & $\begin{array}{c}\text { Міжбюджетні трансферти, } \\
\text { млн грн }\end{array}$ & $\begin{array}{c}\text { Питома вага } \\
\text { міжбюджетних } \\
\text { трансфертів, \% }\end{array}$ \\
\hline 2012 & 212692 & 124460 & 58,5 \\
\hline 2013 & 208216 & 115848 & 55,6 \\
\hline 2014 & 219618 & 130601 & 59,5 \\
\hline 2015 & 294460 & 173980 & 59,1 \\
\hline 2016 & 366040 & 195395 & 53,4 \\
\hline 2017 & 501569 & 272078 & 54,2 \\
\hline
\end{tabular}

Дані табл. 3 показують, що частка фінансової допомоги від держави місцевим бюджетам за останні 6 років майже не змінюється: питома вага міжбюджетних трансфертів коливається в межах 53-59\% місцевих бюджетів. У відносному виразі найменша їх частка припадає на 2016 р. (53,4\%), але ця цифра також свідчить про те, що більше половини грошових коштів місцевих бюджетів формуються за рахунок трансфертів.

У табл. 4 представлено розподілення трансфертів за їх основними видами протягом 2017 року. Отримані дані показали, що половину надходжень до 
місцевих бюджетів займають субвенції на соціальний захист, що в сумі становить 124,7 млрд грн (3 272,08 млрд грн), або 51\%. Більшу половину таких коштів (близько 64,9 млрд грн) було спрямовано на надання пільг і житлових субсидій населенню на оплату електроенергії, природного газу та інших послуг. Порівняно з 2016 р. збільшилась сума на медичну субвенцію - 56,2 млрд грн $(23 \%)$, із яких 700 млн грн виділяються за програмою «Доступні ліки» (на 2018 р. за цією програмою передбачено уже 1 млрд грн) [10].

Таблиия 4. Надходження до місцевих бюджетів за видами дотацій і субвенцій у 2017 р., складено авторами за джерелом [10]

\begin{tabular}{|c|c|c|}
\hline Вид трансферту & $\begin{array}{c}\text { Кількість місцевих } \\
\text { бюджетів, які отримали } \\
\text { трансферт }\end{array}$ & $\begin{array}{c}\text { Сума трансферту, } \\
\text { млрд грн }\end{array}$ \\
\hline Базова дотація & 738 & 5,8 \\
\hline \multicolumn{3}{|c|}{ Субвенції: } \\
\hline - освітня & 998 & 51,5 \\
\hline $\begin{array}{c}\text { - медична (із них за програмою } \\
\text { «Доступні ліки») }\end{array}$ & 977 & $56,2(0,7)$ \\
\hline $\begin{array}{c}\text { - на соціальний захист (включає } \\
\text { надання пільг і житлових субсидій } \\
\text { населенню) }\end{array}$ & - & $124,7(64,9)$ \\
\hline - на формування інфраструктури ОТГ & 412 & 1,5 \\
\hline $\begin{array}{c}\text { - на соціально-економічний розвиток } \\
\text { окремих територій }\end{array}$ & 622 & 6,2 \\
\hline
\end{tabular}

Найбільша кількість місцевих бюджетів (998) у 2017 р. отримала освітню субвенцію, яка трохи менша за медичну і становить 51,5 млн грн (21\%). Як видно із зазначених даних, в Україні найпроблемнішими у соціальній сфері $\epsilon$ дві галузі - це освіта та охорона здоров'я, які потребують значних інвестицій, ефективних результатів від проведення реформ, стабільної законодавчої бази.

Цікавим є факт невеликої частки базової дотації - трансферт, що надається 3 державного бюджету місцевим бюджетам для горизонтального вирівнювання податкоспроможності територій. Як бачимо, у 2017 році було виділено всього 5,8 млрд грн (2\%), а на розвиток інфраструктури ОТГ 1,5 млрд грн (1\%) [9].

Слід зауважити, що станом на 01.04.2018 ОТГ (без м. Києва) нараховувалось 527 утворень. Загалом, новостворені ОТГ демонструють збільшення автономії місцевих органів влади. Громада має можливість створювати нові господарюючі суб'єкти та мати частку у їхніх статутних капіталах, отримувати дивіденди, розраховувати на додаткову державну фінансову підтримку, залучати іноземні інвестиції шляхом участі у конкурсних проектах інвестиційних програм тощо. Однак, незважаючи на те, що процес децентралізації розвитку ОТГ передбачає передачу місцевому самоврядуванню більше повноважень щодо самостійного формування власних коштів та їх використання, сьогодення показує неспроможність самодостатнього розвитку територіальних громад, які поки що не володіють достатніми ресурсами і планують свій розвиток тільки за участі державного бюджету. 
Проблематичним, на наш погляд, $\epsilon$ те, що за напрямами розподілення трансфертів спостерігається спрямування коштів державного бюджету не на допомогу розвитку підприємництва та покращення соціально-економічного стану, а на покриття видатків тих територій, які самостійно не спроможні забезпечити економічне зростання. Саме тому важливим $є$ надання трансфертів, адже грошова допомога повинна надаватися перш за все на розвиток, а вже потім на сплату видатків. 3 цих позицій доцільною є зміна механізму бюджетного вирівнювання та нова стратегія фінансової допомоги регіонам i місцевим бюджетам. Відхід від нинішньої системи трансфертів має бути поступовим, максимально комфортним та ефективним для місцевих бюджетів. Ключовою тезою нової стратегії підтримки самоврядування і місцевих бюджетів $є$ те, що необхідно спрямовувати інвестиції на розвиток підприємницької діяльності, на виконання стимулюючої функції, тобто на формування зацікавленості у місцевих органів самостійно знаходити джерела на покриття видатків і на розвиток. Тільки таким шляхом можна збільшити кількість самодостатніх територій і в перспективі зменшити кількість трансфертів.

\section{Висновки}

Останніми роками формування в Україні бюджетної політики, головним стрижнем якої є міжбюджетні відносини, демонструє позитивні зміни. Має місце процес децентралізації і створення об'єднаних територіальних громад.

У сучасних умовах важливим стає створення ефективної моделі побудови місцевих бюджетів, оскільки ефективне використання коштів прямо впливає на добробут населення та соціально-економічний розвиток регіону і країни в цілому.

У рамках проведеного аналізу виявлено, що протягом 2016-2017 років доходи до місцевих бюджетів збільшились здебільшого за рахунок податку на доходи фізичних осіб. Надходження до місцевих бюджетів від місцевих податків і зборів становлять близько 46\% усіх доходів. На нашу думку, це не дає можливостей для достатнього розвитку територій, тому виникає проблема фінансового вирівнювання, частка трансфертів становить близько $54 \%$.

Частка фінансової допомоги від держави місцевим бюджетам за останні 6 років майже не змінюється: питома вага міжбюджетних трансфертів коливається в межах 53-59\% місцевих бюджетів.

У статті обгрунтовано, що централізація податкових доходів породжує суперечності між учасниками різних рівнів бюджетної системи і робить місцеві бюджети значно залежними від державного бюджету. Запропоновано збільшення частки податкових надходжень, які необхідно залишати на території їх збирання для надання можливості органам місцевого самоврядування вкласти ці кошти у розвиток територій. Оптимізація розподілу доходів місцевих бюджетів може досягатися за умов, коли більше 70\% надходжень буде формуватися за рахунок власних регіональних і місцевих податків. Такий підхід застосовується у розвинутих країнах (Велика Британія, Швейцарія, Швеція, Нова Зеландія, Ісландія, Данія), де частка надходжень за рахунок місцевого податків із зборів становить близько 90\%. Крім того, оптимізація розподілу зменшить ризик корупційних зловживань з боку чиновників. 
Спостерігається спрямування коштів державного бюджету на покриття видатків проблемних територій. У статті запропоновано нову стратегію фінансової допомоги регіонам і місцевим бюджетам, яка спрямована на інвестиції, розвиток підприємницької діяльності та зацікавленості у місцевих органів самостійно знаходити джерела на покриття видатків і на розвиток.

\section{Література}

1. Завора T.M. Аналіз доходів місцевих бюджетів (на прикладі Полтавської області)/ Т.М. Завора, Ю.М. Чумак // Науковий вісник Міжнародного гуманітарного університету. Збірник наукових праць. - Одеса, 2016. - Випуск 17. - С. 135-142.

2. Рябушка Л.Б. Механізм міжбюджетних відносин: проблеми та перспективи розвитку / Л.Б. Рябушка // Вісник Національного Одеського університету. — 2013. — Том 18. Випуск 2/1. - С. $126-129$.

3. Луніна I.O. Капітальні трансферти місцевим бюджетам: підходи до створення ефективної системи управління / І.О. Луніна // Фінанси України. — № 2. — 2011. С. 1—11.

4. Корень Н.В. Міжбюджетні відносини в Україні: сучасний стан та перспективи розвитку / Н.В. Корень// Формування ринкових відносин в Україні: збірник наукових праць. - Київ, 2011. — № 11(126). - С. 48-52.

5. Обуховська К. Економіка України - 2017: більше зростання і менше інфляції / К. Обуховська // Finance.ua [Електронний ресурс]. - Режим доступу : https://news.finance.ua/ua/news/-/392088/ekonomika-ukrayiny-2017-bilshe-zrostannya-i-menshe-inflyatsiyi.

6. Волохова I.C. Міжбюджетні відносини в Україні: сучасний стан та перспективи розвитку: монографія / І.С. Волохова. — Одеса : Атлант, 2010. — 234 с.

7. Бюджетний кодекс України від 08.07.2010 №2456 - VI / [Електронний ресурс]. Режим доступу : http: // zakonrada.gov.ua/laws/show/79-19.

8. Бюджетний моніторинг / Інститут бюджету та соціально-економічних досліджень // Офіційний сайт. [Електронний ресурс]. - Режим доступу : http://www.ibser.org.ua/UserFile/BudgetMonitor. - Назва з екрана.

9. Офіційний сайт Державної служби статистики України [Електронний ресурс] Режим доступу : http://www.ukrstat.gov.ua - 20.06.2018 - Назва з екрана.

10. Державна казначейська служба України [Електронний ресурс]. - Режим доступу : $\mathrm{http}: / /$ www.treasury.gov.ua/main/uk/index.

11. Костирко Л.А. Механізм регулювання міжбюджетних відносин в Україні: пріоритети, інструменти, перспективи: монографія / Л.А. Костирко, Н.Ю. Велентейчик. Сєвєродонецьк: вид-во СНУ ім. В.Даля, 2016. — 280 с.

12. Закон України «Про стимулювання розвитку регіонів» / Редакція від 02.12.2012, підстава 5463 - VI [Електронний ресурс] — Режим доступу : http://zakon.rada.gov.ua/laws/show/2850-15. 